\title{
Effect of Aging on the Properties of Asphalt and Asphalt Mixtures ${ }^{1}$ Efecto del envejecimiento en las propiedades del asfalto y de las mezclas asfálticas ${ }^{2}$
}

\author{
Carlos Hernando Higuera Sandoval ${ }^{3}$ \\ Xiomara Vanessa Camargo Amaya ${ }^{4}$ \\ Edwin Alexander Suárez Molano ${ }^{5}$
}

doi:10.11144/Javeriana.jyu19-2.eapa

How to cite this article:

C.H. Higuera Sandoval, X.V. Camargo Amaya, and E.A. Suárez Molano, "Effect of aging on the properties of asphalt and asphalt mixtures", Ing. Unv., vol. 19, no. 2, pp. 335-349, 2015. http://dx.doi.org/10.1114/javeriana.iyu19-2.eapa

\footnotetext{
' Reception date: August $10^{\text {th }}$, 2014. Acceptance date: January 29't, 2015 . This article is derived from a research project called Effect of Aging on the Properties of Asphalt and Asphalt Mixtures. Code or Register number SGI-1376, developed by Group for Research and Development in Road Infrastructure (Grinfravial), of Transport and Roads Department. University of Pedagogy and Technology of Colombia, Tunja, Colombia.

${ }^{2}$ Fecha de recepción: 10 de agosto de 2014. Fecha de aceptación: 29 de enero de 2015. Este artí́culo se deriva del proyecto de investigación denominado Efecto del envejecimiento en las propiedades del asfalto y de las mezclas asfálticas. Código de registro SGI-1376, desarrollado por el Grupo de Investigación y Desarrollo en Infraestructura de Vías (Grinfravial) de la Universidad Pedagógica y Tecnológica de Colombia, Tunja, Colombia.

${ }^{3}$ Transport and Road Engineer from University of Pedagogy and Technology of Colombia. Specialist in Roads from Technical University of Madrid, Spain. Master in Land Routes, University of Cauca, Colombia. Associate professor, Transport and Roads Department, University of Pedagogy and Technology of Colombia, Tunja, Colombia. E-mail: carlos.higuera@uptc.edu.co ${ }^{4}$ Transport and Road Engineer, University of Pedagogy and Technology of Colombia, Tunja Colombia.

E-mail: vanner_5@hotmail.com

${ }^{5}$ Transport and Road Engineer, University of Pedagogy and Technology of Colombia, Tunja, Colombia.

E-mail: aduns2@hotmail.com
} 


\section{Abstract}

This article presents the results of the analysis of the effect of aging on the properties of asphalt and asphalt mixtures. The objective of this study was to compare the properties of the original asphalt and aged asphalt and the dynamic modulus of asphalt mixtures. The long-term aging was simulated by using Pressure Asphalt Vessel (PAV). Marshall and RAMCODES methodologies were used to determine the formula of work; values of dynamic modulus of designed mixtures were obtained by the indirect tensile test, using the Nottingham Asphalt Tester (NAT). The results showed an increase in the rigidity of the aged asphalt. Also, an increase of the stability and a decreased flow in the mixtures made with this type of binder was found. The dynamic modulus values of the mixtures containing aged asphalt showed an increase up to three times compared with those elaborated with original asphalt mixtures.

\section{Keywords}

aging; asphalt; asphalt mixture; characterization; dynamic modulus; oxidation; pressure asphalt vessel

\section{Resumen}

El presente artículo muestra los resultados del análisis del efecto del envejecimiento en las propiedades del asfalto y de las mezclas asfálticas. El objetivo de esta investigación fue comparar las propiedades del asfalto original y el asfalto envejecido así como el módulo dinámico de las mezclas asfálticas. Se simuló el envejecimiento a largo plazo mediante el uso de la Cámara de Envejecimiento a Presión (PAV). Se utilizaron las metodologías Marshall y RAMCODES para determinar la fórmula de trabajo; los valores de módulos dinámicos de las mezclas diseñadas se obtuvieron mediante el ensayo de tracción indirecta, utilizando el equipo Nottingham Asphalt Tester (NAT). Los resultados obtenidos mostraron un aumento en la rigidez de los asfaltos envejecidos, se encontró un aumento de la estabilidad y disminución del flujo en las mezclas realizadas con este tipo de ligante; en los valores de módulo dinámico, las mezclas con contenido de asfaltos envejecidos presentaron un aumento de hasta tres veces al compararlas con las mezclas realizadas con asfaltos originales.

\section{Palabras clave}

asfalto; caracterización; cámara de envejecimiento a presión; envejecimiento; mezclas asfálticas; módulos dinámicos; oxidación 


\section{Introduction}

Two types of aging affect the asphalt, in the short and long term; the first occurs at the moment of preparation of the hot asphalt mixture, while the second one will be happening during the useful life of the layer [1]. Both events cause a change in the physicochemical properties of the material, which will directly affect its durability, reducing the useful life period initially expected [2].

One of the principal factors that causes the aging is the asphalt binder oxidation. The oxygen acts over the more reactive components of the asphalt, appearing primarily as hardening [3], loss of viscoelastic consistency, fissuring, and cracking. These pathologies vary according to the type of asphalt, appearing much faster in those higher viscosities than in others with lesser values.

Since the usefulness of the highway is affected by the pathologies generated by the aging process, it is necessary to perform different research projects with the idea of decreasing the effects of this phenomenon, in order to have a greater feeling of comfort and security at the time of making use of this infrastructure.

\section{Materials and Methods}

Initially, for the development of this research about the comparison of the properties of the asphalt penetration 60-70 and 80-100, a characterization of the materials that will be used in the preparation of the mixtures was performed. Then, its incidence on the dynamic modulus of asphalt mixtures before and after aging by Pressure Asphalt Vessel (PAV) test would be determined. Similarly, the verification of the compliance of said materials with the INVIAS-2007 and IDU-2005 specifications would be revised.

Then, a long-term aging process was carried out for the original Colombian asphalts 60-70 and 80-100, using PAV. The properties of these aged binders were also determined. Hot Type-2 (MDC-2) asphalt mixtures were manufactured with the original and aged asphalts by implementing the MARSHALL and RAMCODES methodologies, and the optimal percentage of asphalt in 
the mixtures was determined, based on which the existing dynamic modulus would be determined.

\subsection{Asphalt Aging (PAV Test)}

The article INV. E 751-07 describes the procedure to be followed to produce the accelerated aging of asphalts binders through a method with pressurized air and high temperatures. The test simulates the aging of the asphalt by oxidation [4].

The laboratory process is described below, followed by the process implemented for the aging of penetration asphalts 60-70 and 80-100.

- The PAV contains a tray holder in which up to 10 steel trays can be placed. The tray was put inside the pressure chamber. Then, the aging temperature was selected, in this case, it was $100{ }^{\circ} \mathrm{C}$ and the pressure chamber was preheated. See Figure 1.

Figure 1. Pressure asphalt vessel and tray holder

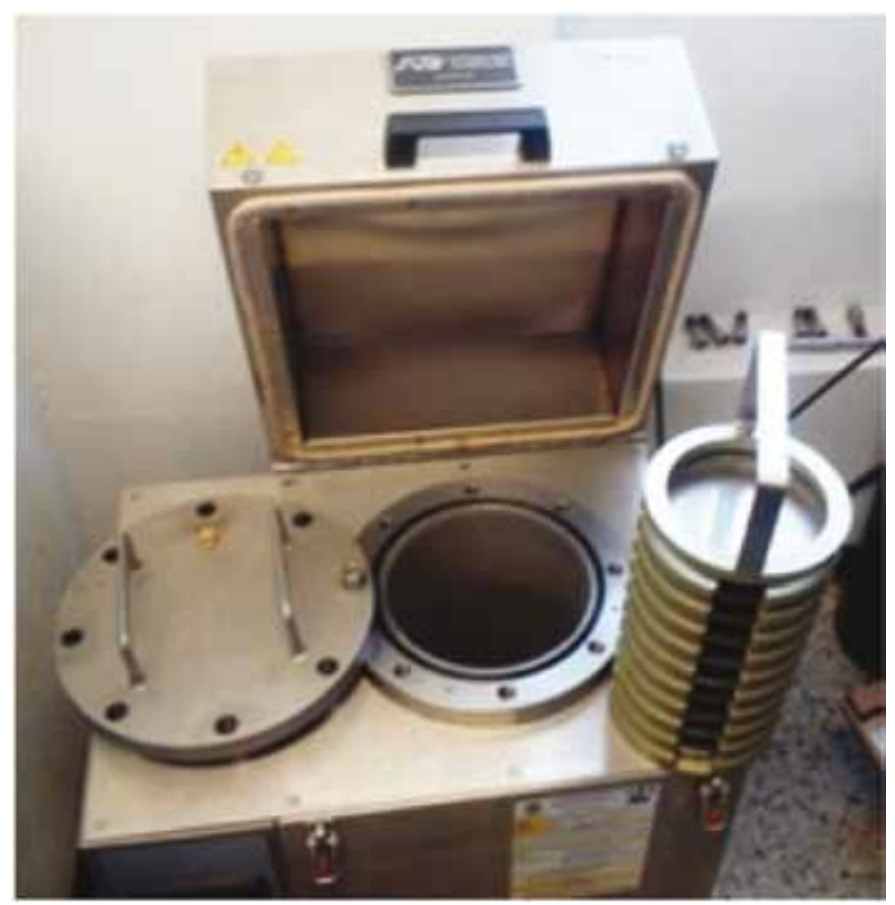

Source: authors' own elaboration 
- The asphalt is heated to the softening temperature. The 10 stainless steel trays were placed on a balance, adding $50 \pm 0.5 \mathrm{~g}$ of asphalt binder to each one. See Figure 2.

Figure 2. Asphalt trays

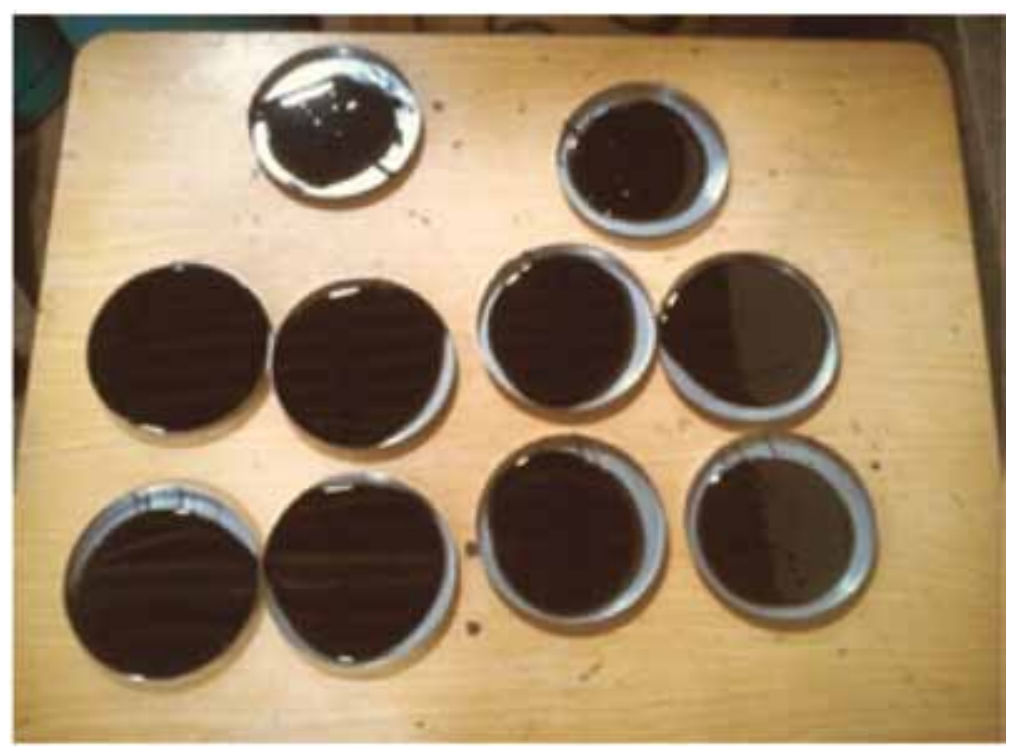

Source: authors' own elaboration

- The trays with asphalt binder were put on the tray holder. Then, the full tray holder was introduced into the pressure chamber and closed. The introduction of the tray holder was performed quickly so the temperature inside the aging chamber did not drop.

- The time recording of the test $(20 \mathrm{~h})$ started after the temperature inside the pressure chamber reached a near aging temperature and an air pressure of $2.1 \pm 0.1 \mathrm{MPa}$ was applied.

- Once the $20 \mathrm{~h}$ period of the test finished, the pressure inside the chamber was reduced using the relief valve.

- The tray holder with the trays was removed from the chamber and they were put inside an oven at $163{ }^{\circ} \mathrm{C}$ during $15 \mathrm{~min}$, until the asphalt was sufficiently fluid.

- The trays were removed from the oven and the hot residue was poured into a container. See Figure 3. 
Figure 3. Ledge with aged asphalt

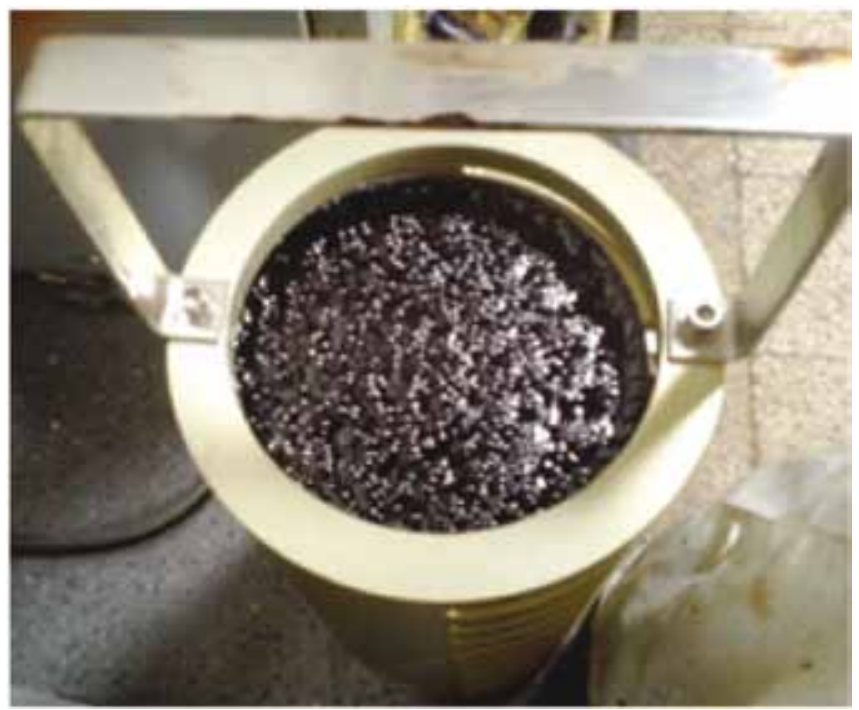

Source: authors' own elaboration

\section{Results and Discussion}

\subsection{Materials Characterization}

It is important to know the physical characteristics of stone aggregate and asphalt for their use with different asphalts, as they are the main components of the asphalt mixture and their characteristics have an important incidence in the behavior of the mixtures. In addition, their characteristics vary according to the area where they were extracted; this is why aggregates exploited in some quarries may differ from others, due to their geological formation. The same happens with asphalts that are affected by the extraction and refining process.

\subsection{Characterization of Stone Aggregate}

To meet the design of hot dense type 2 (MDC-2) asphalt mixtures, crushed aggregates from the Paz de Rio quarry were used. The results obtained from the characterization of stone aggregate through laboratory tests are presented in Table 1.

The measured properties of the aggregates meet the specifications of article 400 of INVIAS (2007) [5], in contrast to the IDU-05 standard, for which the flattening index did not met the criteria. 
Table 1. Results of Stone aggregate test

\begin{tabular}{|l|l|l|c|c|l|}
\hline \multicolumn{7}{|c|}{ Crushed Quarry Paz de Rio } \\
\hline \multicolumn{2}{|c|}{ Characteristic } & \multicolumn{1}{|c|}{ Standard } & $\begin{array}{c}\text { Result } \\
(\%)\end{array}$ & $\begin{array}{c}\text { INVIAS } \\
(\%)\end{array}$ & $\begin{array}{r}\text { IDU } \\
(\%)\end{array}$ \\
\hline Los Ángeles abrasion & Rolling & $\begin{array}{l}\text { INV. E 218-07 } \\
\text { IDU 510-05 }\end{array}$ & 18.90 & 25 max. & 25 max. \\
\hline $\begin{array}{l}\text { Losses fastness test } \\
\text { (Sodium sulfate) }\end{array}$ & $\begin{array}{l}\text { INV. E 220-07 } \\
\text { IDU 510-05 }\end{array}$ & 5.72 & 12 max. & N.A. \\
\hline $\begin{array}{l}\text { Fractured particles 2 } \\
\text { sides }\end{array}$ & Rolling & $\begin{array}{l}\text { INV. E 227-07 } \\
\text { IDU 510-05 }\end{array}$ & 97.7 & 60 min. & 75 min. \\
\hline $\begin{array}{l}\text { Elongation index } \\
\text { Flattening index }\end{array}$ & $\begin{array}{l}\text { INV. E 230-07 } \\
\text { IDU 510-05 }\end{array}$ & 21.9 & 35 max. & 20 max. \\
\hline
\end{tabular}

INVIAS: Instituto Nacional de Vías; IDU: Instituto de Desarrollo Urbano de Bogotá.

Source: authors' own elaboration

\subsection{Characterization of Original and Aged Penetration Asphalts 60-70 and 80-100}

The asphalts used in this research are penetration asphalts 60-70 and 80-100 coming from Manufacturas y Procesos Industriales Ltda. (MPI), which is located in Barrancabermeja (Santander).

The following charts present the results obtained for the tests that were applied with the PAV equipment to the original and aged asphalts, considering the provisions of the INVIAS-07 and IDU-05 standards. See Tables 2 and 3 .

The results obtained from the tests performed on both types of asphalts show that original asphalts met with the requirements demanded by the INVIAS-07 and IDU-05 standards. On the other hand the binders that have been aged die not meet the majority of parameters required; changes of penetration values, ductility, softening point, and viscosity are notorious, indicating an increase in the rigidity of the asphalt. The following rheological curves of the aged asphalts, obtained through the testing of asphalt viscosity with the Brookfield Rotational Viscometer (INV. E 717), demonstrates an increase in viscosity of aged asphalts in comparison to originals. See Figure 4 [6]-[8]. 
Table 2. Results of characterization of original and aged asphalt 60-70

\begin{tabular}{|c|c|c|c|c|c|c|c|}
\hline \multicolumn{8}{|c|}{ Penetration Asphalt 60-70 MPI Plant } \\
\hline \multirow{2}{*}{ Test } & \multirow{2}{*}{ Standard } & \multicolumn{2}{|c|}{ INVIAS } & \multicolumn{2}{|c|}{ IDU } & \multicolumn{2}{|c|}{ Measured Value } \\
\hline & & Min. & Max. & Min. & Max. & $60-700$ & $60-70 \mathrm{~A}$ \\
\hline $\begin{array}{l}\text { Penetration } \\
(1 / 10 \mathrm{~mm})\end{array}$ & $\begin{array}{l}\text { INV. E 706-07 } \\
\text { IDU 200-05 }\end{array}$ & 60 & 70 & 60 & 70 & 64.3 & 37.7 \\
\hline Ductility (mm) & $\begin{array}{l}\text { INV. E 724-07 } \\
\text { IDU 200-05 }\end{array}$ & 100 & - & 100 & - & $>100$ & 12.0 \\
\hline Softening point $\left({ }^{\circ} \mathrm{C}\right)$ & $\begin{array}{l}\text { INV. E 712-07 } \\
\text { IDU 200-05 }\end{array}$ & 45 & 55 & 45 & 55 & 47.5 & 59.5 \\
\hline Specific weight & \begin{tabular}{|l|} 
INV. E 707-07 \\
IDU 200-05 \\
\end{tabular} & & & & & 1.016 & 1.020 \\
\hline $\begin{array}{l}\text { Ignition point (Cleveland } \\
\text { open-cup) }\left(C^{\circ}\right)\end{array}$ & \begin{tabular}{|l|} 
INV. E 709- 07 \\
IDU 200-05 \\
\end{tabular} & 230 & - & 232 & - & 286.9 & 251.9 \\
\hline Viscosity at $60{ }^{\circ} \mathrm{C}(\mathrm{P})$ & \begin{tabular}{|l|} 
INV. E 717-07 \\
IDU 200-05
\end{tabular} & 1500 & - & 1500 & 3000 & 2312 & 12891 \\
\hline \multicolumn{6}{|l|}{ Mixture temperature } & $146.1-154.2$ & $173-178$ \\
\hline \multicolumn{6}{|l|}{ Compaction temperature } & $136.1-140.0$ & $161-167$ \\
\hline
\end{tabular}

INVIAS: Instituto Nacional de Vías; IDU: Instituto de Desarrollo Urbano de Bogotá.

Source: authors' own elaboration

Table 3. Results of characterization of original and aged asphalt $80-100$

\begin{tabular}{|c|c|c|c|c|c|c|c|}
\hline \multicolumn{8}{|c|}{ Penetration Asphalt 80-100 MPI Plant } \\
\hline \multirow{2}{*}{ Test } & \multirow{2}{*}{ Standard } & \multicolumn{2}{|c|}{ INVIAS } & \multicolumn{2}{|c|}{ IDU } & \multicolumn{2}{|c|}{ Measured value } \\
\hline & & Min. & Max. & Min. & Max. & $80-1000$ & $80-100 \mathrm{~A}$ \\
\hline $\begin{array}{l}\text { Penetration } \\
(1 / 10 \mathrm{~mm})\end{array}$ & $\begin{array}{l}\text { INV. E 706-07 } \\
\text { IDU 200-05 }\end{array}$ & 80 & 100 & 80 & 100 & 86.3 & 62 \\
\hline Ductility (mm) & $\begin{array}{l}\text { INV. E 724-07 } \\
\text { IDU 200-05 }\end{array}$ & 100 & - & 100 & - & $>100$ & 62 \\
\hline $\begin{array}{l}\text { Softening point (Ring } \\
\text { and Ball method) }\left({ }^{\circ} \mathrm{C}\right)\end{array}$ & $\begin{array}{l}\text { INV. E } 71207 \\
\text { IDU 200-05 }\end{array}$ & 45 & 55 & 42 & 52 & 46.5 & 48 \\
\hline Specific weight & $\begin{array}{l}\text { INV. E } 70707 \\
\text { IDU 200-05 } \\
\end{array}$ & & & & & 1.047 & 1.015 \\
\hline $\begin{array}{l}\text { Ignition point (Cleveland } \\
\text { open-cup) }\left({ }^{\circ} \mathrm{C}\right)\end{array}$ & \begin{tabular}{|l|} 
INV. E 70907 \\
IDU 200-05
\end{tabular} & 230 & - & 232 & - & 316.9 & 263.9 \\
\hline Viscosity at $60{ }^{\circ} \mathrm{C}(\mathrm{P})$ & $\begin{array}{l}\text { INV. E } 71707 \\
\text { IDU 200-05 }\end{array}$ & 1000 & - & 1000 & 2000 & 1238 & 4549 \\
\hline \multicolumn{6}{|l|}{ Mixture temperature } & $144-150$ & $161-165$ \\
\hline \multicolumn{6}{|l|}{ Compaction temperature } & $132.3-137.8$ & $148-155$ \\
\hline
\end{tabular}

INVIAS: Instituto Nacional de Vías; IDU: Instituto de Desarrollo Urbano de Bogotá.

Source: authors' own elaboration 
Figure 4. Rheological curves for original and aged asphalts

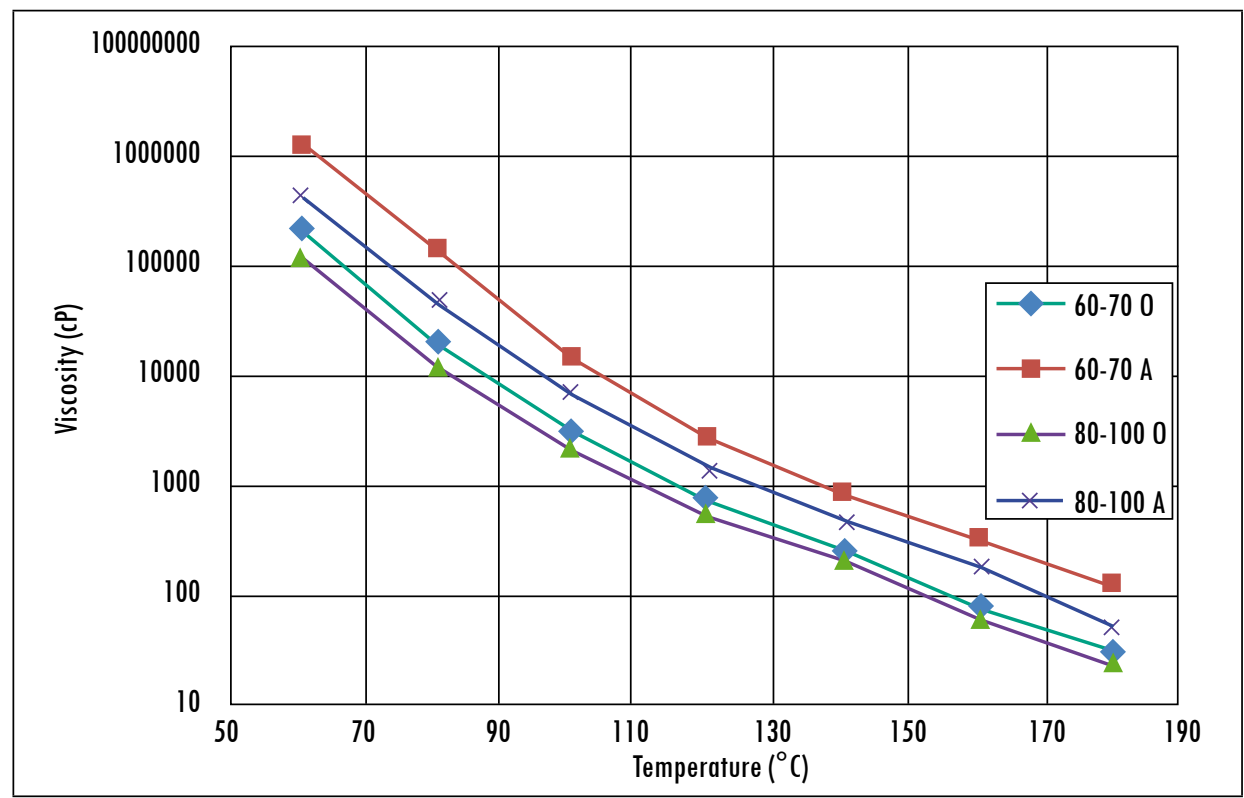

Source: authors' own elaboration

\subsection{Effect of Aging on Asphalts Mixtures}

Four mixtures were made with original and aged asphalts. They were named 60-70 O, 60-70 A, 80-100 O, and 80-100 A. With the results obtained from the laboratory tests performed on the four mixtures, and the comparison with the corresponding INVIAS-07 and IDU-05 specifications, it can be observed that the mixtures fulfill almost all the required specifications.

Tables 4 and 5 present the results obtained from the comparison for hot dense type 2 (MDC-2) mixtures, made with original and aged penetration asphalts 60-70 and 80-100.

The analysis of the results show that the principal change between the mixtures made with original and aged asphalts can be seen in the stability and flow parameters. The 60-70 A and 80-100 A mixtures had higher stabilities and lowers flows in comparison with the 60-70 $\mathrm{O}$ and 80-100 $\mathrm{O}$ mixtures.

Furthermore, the value of stability-flow ratio was evaluated, as INVIAS-07 and IDU-05 standards specify this parameter. The degree of fragility of the asphalt mixtures can be elaborated with this value. The next chart presents the results of stability/flow ratio. See Tables 6 and 7 . 
344 Carlos Hernando Higuera Sandoval, Xiomara Vanessa Camargo Amaya, Edwin Alexander Suárez Molano

Table 4. Comparison between obtained results for 60-70 0, 60-70 A mixtures and specifications

\begin{tabular}{|c|c|c|c|c|c|c|c|c|c|c|}
\hline \multirow{3}{*}{$\begin{array}{l}\text { Parameter } \\
\text { Traffic level }\end{array}$} & \multicolumn{6}{|c|}{$M D C-2$} & \multicolumn{2}{|c|}{ Value } & \multirow{3}{*}{$\begin{array}{c}\text { INVIAS } \\
-\end{array}$} & \multirow{3}{*}{$\begin{array}{c}\text { IDU } \\
-\end{array}$} \\
\hline & \multicolumn{3}{|c|}{ INVIAS-07 } & \multicolumn{3}{|c|}{ IDU-05 } & $60-70$ & $60-70$ & & \\
\hline & NTI & NT2 & NT3 & TO-Tl & T2-T3 & T4-T5 & - & - & & \\
\hline $\begin{array}{l}\text { Asphalt } \\
\text { optimal (\%) }\end{array}$ & - & - & - & - & - & - & 6.1 & 6.2 & - & - \\
\hline Gbulk $\left(\mathrm{g} / \mathrm{cm}^{3}\right)$ & - & - & - & - & - & - & 2.352 & 2.334 & - & - \\
\hline$\% \mathrm{Va}$ & $3-5$ & $3-5$ & $4-6$ & $3-5$ & $3-5$ & $4-6$ & 4.2 & 5 & Fulfill & Fulfill \\
\hline$\% \mathrm{VAM}$ & $\geq 15$ & $\geq 15$ & $\geq 15$ & $\geq 15$ & $\geq 15$ & $\geq 15$ & 15.9 & 16.6 & Fulfill & Fulfill \\
\hline$\%$ VFA & $65-80$ & $65-78$ & $65-75$ & $70-80$ & $65-78$ & $65-75$ & 73 & 70.5 & Fulfill & Fulfill \\
\hline Stability $(\mathrm{kg})$ & 500 & 750 & 900 & 600 & 750 & 900 & 1228.2 & 2070 & Fulfill & Fulfill \\
\hline Flow (mm) & $2-4$ & $2-4$ & $\begin{array}{l}2- \\
3,5\end{array}$ & $2-4$ & $2-4$ & $2-3.5$ & 3.48 & 3.23 & Fulfill & Fulfill \\
\hline
\end{tabular}

INVIAS: Instituto Nacional de Vías; IDU: Instituto de Desarrollo Urbano de Bogotá.

Source: authors' own elaboration

Table 5. Comparison between Obtained results for 80-100 0, 80-100 A mixtures and specifications

\begin{tabular}{|c|c|c|c|c|c|c|c|c|c|c|}
\hline \multirow{3}{*}{$\begin{array}{l}\text { Parameter } \\
\text { Traffic level }\end{array}$} & \multicolumn{6}{|c|}{$M D C-2$} & \multicolumn{2}{|c|}{ Value } & \multirow{3}{*}{$\begin{array}{c}\text { INVIAS } \\
-\end{array}$} & \multirow{3}{*}{$\begin{array}{c}\text { IDU } \\
-\end{array}$} \\
\hline & \multicolumn{3}{|c|}{ INVIAS-07 } & \multicolumn{3}{|c|}{ IDU-05 } & $80-100$ & $80-100$ & & \\
\hline & NTI & NT2 & NT3 & TO-Tl & T2-T3 & T4-T5 & - & - & & \\
\hline $\begin{array}{l}\text { Asphalt } \\
\text { optimal (\%) }\end{array}$ & - & - & - & - & - & - & 5.8 & 6 & - & - \\
\hline Gbulk $\left(\mathrm{g} / \mathrm{cm}^{3}\right)$ & - & - & - & - & - & - & 2.354 & 2.356 & - & - \\
\hline$\% \mathrm{Va}$ & $3-5$ & $3-5$ & $4-6$ & $3-5$ & $3-5$ & $4-6$ & 4.9 & 4.21 & Fulfill & Fulfill \\
\hline$\%$ VAM & $\geq 15$ & $\geq 15$ & $\geq 15$ & $\geq 15$ & $\geq 15$ & $\geq 15$ & 15.6 & 15.73 & Fulfill & Fulfill \\
\hline$\%$ VFA & $65-80$ & $65-78$ & $65-75$ & $70-80$ & $65-78$ & $65-75$ & 68.1 & 73.24 & Fulfill & $\begin{array}{l}\text { Does not } \\
\text { meet } \\
80-100 \\
\text { O in } \\
\text { T0-T1 }\end{array}$ \\
\hline Stability $(\mathrm{kg})$ & 500 & 750 & 900 & 600 & 750 & 900 & 1072.3 & 1836 & Fulfill & Fulfill \\
\hline Flow (mm) & $2-4$ & $2-4$ & $2-3.5$ & $2-4$ & $2-4$ & $2-3,5$ & 3.45 & 3.33 & Fulfill & Fulfill \\
\hline
\end{tabular}

Obtained results for 80-100 0, 80-100 A mixtures and specifications

Source: authors' own elaboration 
Table 6. Results of stability/flow ratio for asphalt mixturess $60-700$ and $60-70 \mathrm{~A}$

\begin{tabular}{|c|c|c|c|c|c|c|c|c|}
\hline \multicolumn{9}{|c|}{ Stability/Flow Ratio } \\
\hline \multicolumn{3}{|c|}{ INVIAS-07 } & \multicolumn{3}{|c|}{ IDU-05 } & \multicolumn{2}{|c|}{$60-70$} & \multirow[b]{2}{*}{ Acceptation } \\
\hline NTl & NT2 & NT3 & TO-Tl & T2-Т3 & T4-T5 & $\begin{array}{c}60-70 \\
0\end{array}$ & $\begin{array}{c}60-70 \\
\mathrm{~A}\end{array}$ & \\
\hline $200-400$ & $300-500$ & $300-600$ & $200-400$ & $300-500$ & $300-600$ & 352.9 & 640.9 & $\begin{array}{l}\text { The mixture } \\
60-70 \mathrm{O} \\
\text { fulfills, while } \\
60-70 \text { A does } \\
\text { not meet the } \\
\text { specifications }\end{array}$ \\
\hline
\end{tabular}

Source: authors' own elaboration

Table 7. Results of stability/flow ratio for asphalt mixtures 80-100 0 and 80-100 A

\begin{tabular}{|c|c|c|c|c|c|c|c|c|}
\hline \multicolumn{7}{|c|}{ Stability/Flow Ratio } & \multirow{2}{*}{ Acceptation } \\
\cline { 1 - 5 } NT1 & NT2 & NT3 & T0-T1 & T2-T3 & T4-T5 & $80-1000$ & $80-100$ A & \\
\hline 200-400 & $300-500$ & $300-600$ & $200-400$ & $300-500$ & $300-600$ & $310-8$ & 551.4 & $\begin{array}{l}\text { The mixture } \\
80-70 \text { O fulfills, } \\
\text { while 80-100 A } \\
\text { does not meet } \\
\text { the specifications }\end{array}$ \\
\hline
\end{tabular}

Source: authors' own elaboration

The above results suggest that the ratio of the 60-70 A mixture is much greater (by at least $82 \%$ ) than that of the $60-70 \mathrm{O}$ mixture. The same happens with the 80-100 A mixture, which had an increase of $77 \%$ on this value in comparison with 80-100 O. It can be determined through this relationship that the mixtures made with aged asphalts do not meet the specifications; since this is an acceptance criteria in the constructive process, these mixtures should be rejected, because they are considered fragile and rigid and can cause early cracking in the asphalt layer. This kind of behavior is typical in asphalt layers that have suffered long-term aging. When volatilization appears on the asphalt components, the amount of asphaltenes increases, which causes the binder to behave like a solid, producing higher rigidity and deterioration of its condition. 


\subsection{Dynamic Modulus Test with NAT Equipment (Nottingham Asphalt Tester)}

Twelve briquettes were manufactured with the optimum asphalt percentage obtained from the Marshall Methodology. For the dynamic module test of the mixtures made with the original and aged asphalts, these mixtures were compacted using the gyratory compactor. The indirect tensile test was performed according to the INV.-E-749-07 standard, at three different temperatures (5, 25 , and $40{ }^{\circ} \mathrm{C}$ ) and a frequency of $10 \mathrm{Hertz}$. The dynamic modulus were registered in two positions, $0^{\circ}$ and $90^{\circ}$. The obtained results are presented in Table 8 .

Table 8. Dynamic Modulus result for original and aged asphalt mixtures $60-70$ and 80-100

\begin{tabular}{|c|c|c|c|c|c|}
\hline \multirow{2}{*}{ Temperature $\left({ }^{\circ} \mathrm{C}\right)$} & \multirow{2}{*}{$\begin{array}{l}\text { Briquette } \\
\text { position }\end{array}$} & \multicolumn{4}{|c|}{ Dynamic Module } \\
\hline & & $60-700$ & $60-70 \mathrm{~A}$ & $80-1000$ & $80-100 \mathrm{~A}$ \\
\hline \multirow{3}{*}{5} & 0 & 12410 & 15669 & 10975 & 16251 \\
\hline & 90 & 12225 & 17457 & 10912 & 15764 \\
\hline & Mean Value & 12318 & 16563 & 10944 & 16008 \\
\hline \multirow{3}{*}{25} & 0 & 2537 & 6715 & 3212 & 5792 \\
\hline & 90 & 2546 & 6710 & 2470 & 5866 \\
\hline & Mean Value & 2542 & 6713 & 2841 & 5829 \\
\hline \multirow{3}{*}{40} & 0 & 1116 & 2360 & 545 & 774 \\
\hline & 90 & 1066 & 2450 & 501 & 740 \\
\hline & Mean Value & 1091 & 2405 & 523 & 757 \\
\hline
\end{tabular}

Source: authors' own elaboration

At a temperature of $5{ }^{\circ} \mathrm{C}$ the high dynamic modulus values are notable. As the test temperature increases, the dynamic module values decrease. It is observed that at a temperature of $40{ }^{\circ} \mathrm{C}$ the value of dynamic modulus decrease significantly.

The following figures show the obtained results of dynamic modules for each mixture. These curves are denominated master curves of dynamic modulus, which can be complemented with tests performed at different frequencies. For this research we only used a $10 \mathrm{~Hz}$ frequency, which is the equivalent to a load application time of $0.02 \mathrm{~s}$. 
Figure 5 shows the change that the dynamic modulus presents when aged asphalt is used in the elaboration of the asphaltic mixtures. Mixtures 60-70 A and 80-100 A had higher dynamic modules, which is consistent with rigidification presented by the long-term aging phenomena.

Figure 5. Comparison of Dynamic modulus of mixtures made with original and aged asphalts

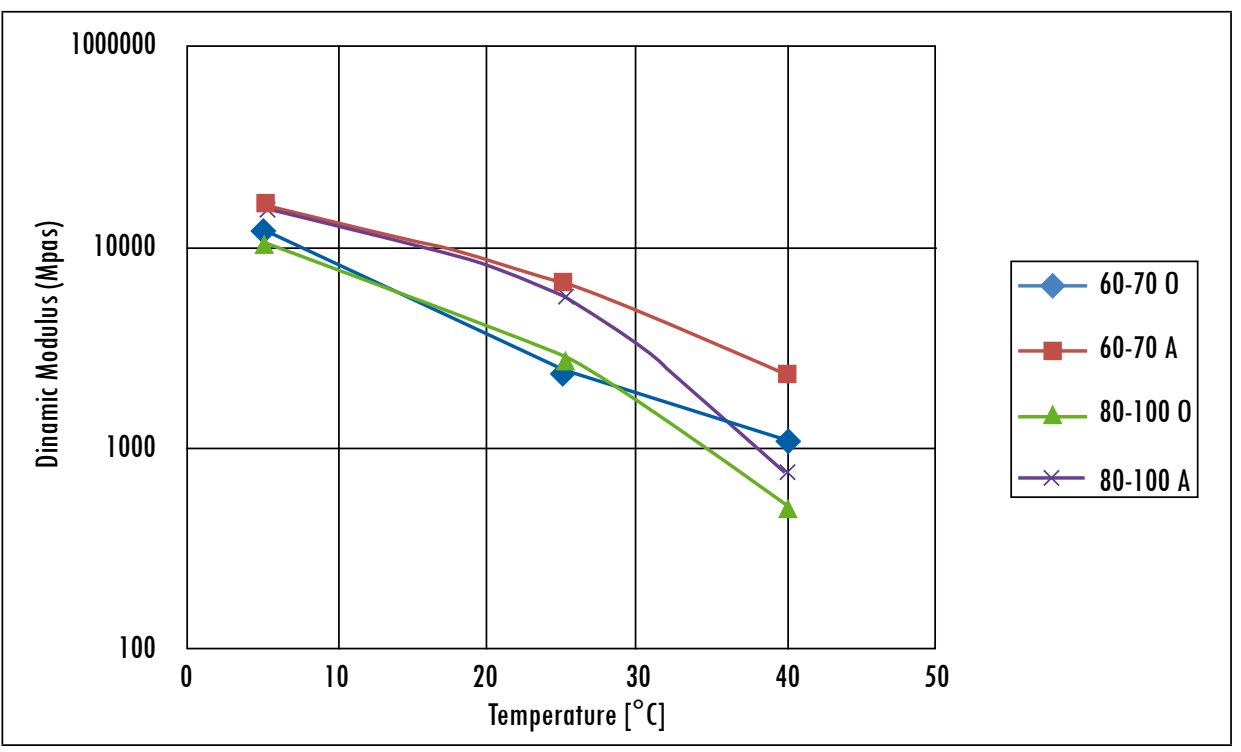

Source: authors' own elaboration

Asphalt mixtures made with aged asphalts present a similar behavior in comparison with original asphalts in terms of dynamic modulus for a temperature of $5{ }^{\circ} \mathrm{C}$. This could be possible because the viscoelastic behavior of the material does not develop completely at low temperatures, but the effect an increase in temperature already makes evident the change between different mixtures.

\section{Conclusions}

The variation in the asphalt properties is appreciable when there is long-term aging. Parameters like ductility and penetration present lower values, and a higher softening point higher in comparison with the results of original asphalts. This is due to the increment in viscosity suffered by aged binders. The four mixtures designed by Marshall and RAMCODES methodologies with original and aged asphalts fulfill the majority of criteria for different traffic levels present in the specifications of INVIAS-07 and IDU 05, except for the 80-100 O 
mixture, which does not meet the criteria of voids filled asphalt percentage (\%VFA) for T0-T1 traffic of IDU-05 standard.

The volumetric values obtained did not present a higher variation when compared between the mixtures elaborated with original and aged penetration asphalts 60-70 and 80-100. Because at the moment of heating these binders for the elaboration of the mixture allowed them to have temperatures in the $170 \pm 20$ centistokes range, almost the same state of viscosity was obtained. In addition, in the four mixtures the same aggregate extracted from the Agregados Paz del Río quarry were used. In regards to the briquettes prepared on the Marshall press, it was established that the stability values were higher for mixtures made with aged asphalts (60-70 $\mathrm{A}$ and 80-100 A) than those made with original asphalts (60-70 $\mathrm{O}$ and 80-100 O). Likewise, a decrease in the flow of mixtures with aged asphalt was observed, in comparison with those made with original asphalts.

A necessary value for the acceptation of asphalt layers is stability-flow ratio, which is taken into account by the INVIAS-07 and IDU-05 specifications. The degree of fragility and ductility of the asphalt mixtures used in road constructions is evaluated with this parameter. For this research it was observed that the 60-70 A and 80-100 A mixtures do not meet this criteria, showing higher values than the required intervals, which means that these mixtures could be too fragile due to rigidification caused by long-term aging of asphalt binder.

According to the behavior present in the master curves of dynamic modulus, it could be observed that the increase of the test temperature caused a decrease in the values of the modulus. As this increase occurs, the binder viscosity which forms the asphaltic mixture decreases, thereby causing it to have less resistance to loads applied on it. It could also be determined that at lowtest temperatures, the four mixtures presented similar modules. This might be possible since the viscoelastic behavior of the material does not fully develop at such temperatures. Thanks to the dynamic modulus values obtained through NAT equipment (Nottingham Asphalt Tester), it could be observed that 60-70 $A$ and 80-100 A mixtures present a higher dynamic module than the mixtures made with original asphalt. This means that mixtures elaborated with aged asphalts are much more rigid. The rigidification present in the asphalt mixtures prevents deformation, a situation that can begin cracking in them, decreasing in this way the existing pavement quality, as usually happens in asphalt layers that have suffered long-term aging. 


\section{Acknowledgements}

Authors express their acknowledgements to the Transport and Roads Department of the Faculty of Engineering of University of Pedagogy and Technology of Colombia for the contribution given to the development of this research project. Similarly, to the Engineer Manuel Sierra, coordinator of the Laboratory of Soils and Pavements of UPTC, for his help and collaboration in the development of research.

\section{References}

[1] W. Fernández, H. Rondón and F. Reyes, "A review of asphalt and asphalt mixture aging”, Ingeniería e Investigación, vol. 33, pp. 5-12, 2012.

[2] X. Vargas y F. Reyes, "El fenómeno de envejecimiento de los asfaltos", Ingeniería e Investigación, vol. 30, pp. 27-44, 2010.

[3] M. Parada, A. J. Lepesqueur y B. Caicedo, Estudio del envejecimiento de mezclas asfálticas por oxidación. Bogotá: Universidad de los Andes, 2005.

[4] Instituto Nacional de Vías. Especificaciones de construcción de carreteras. Norma. INV. E-75107. Bogotá, 2007.

[5] Instituto Nacional de Vías. Normas de ensayos de materiales. Artículo 400-07. Bogotá, 2007.

[6] J. Puello Méndez, N. Afanasjeva y M. Álvarez Cifuentes, "Análisis de la degradación térmica de asfaltos mediante termogravimetría”, Asfaltos y Pavimentos, no. 26, 2013.

[7] R. E. Villegas Villegas, J. P. Aguiar Moya, L. G. Loría Salazar, A. Navas Carro, "De la consistencia al desempeño. Nueva tendencia en la compra, control de calidad y diseño de los asfaltos en Latinoamérica", Asfaltos y Pavimentos, no. 25, 2012.

[8] L. Jaimes Martínez, "Variación de resultados en la determinación de viscosidad de asfaltos y residuos (RTOF) por diferentes métodos”, Asfaltos y Pavimentos, no. 23, 2011. 
